\title{
Algorithmic tools for tripartite data analysis
}

\author{
Charles A Phillips ${ }^{1}$, Erich J Baker ${ }^{2}$, Elissa J Chesler ${ }^{3}$, Michael A Langston ${ }^{1 *}$ \\ From UT-KBRIN Bioinformatics Summit 2014 \\ Cadiz, KY, USA. 11-13 April 2014
}

\section{Background}

Bipartite graphs have many applications. Examples include the modeling of gene-disease associations, substrate-enzyme relationships and protein-protein interactions. Numerous algorithms have been proposed to extract dense subgraphs from bipartite graphs.

\section{Materials and methods}

In this work, tripartite graphs are considered. Applications include comparing two sets of many gene-many disease associations. An algorithm is described that finds a maximum triclique in such a graph. It employs a branching strategy inspired by maximum clique algorithms for general graphs. A binary search tree is used, in which branch nodes in the tree represent vertices in the tripartite graph, and in which branching decisions are based on whether a vertex is in or out of a maximum triclique. A reduction rule is also introduced to filter out irrelevant vertices. This algorithm was developed in the context of GeneWeaver, an online system for the integration of functional genomics experimental results. In this system triclique extraction will enable fast transitive association of diseases based on the similarity of gene-disease associations from many experiments. Computational experience with huge volumes of experimental data is described.

\section{Authors' details}

'Department of Electrical Engineering and Computer Science, University of Tennessee, Knoxville, TN 37996, USA. ${ }^{2}$ Bioinformatics Program, School of Engineering and Computer Science, Baylor University, Waco, TX 76798, USA. ${ }^{3}$ The Jackson Laboratory, Bar Harbor, ME 04609, USA.

Published: 29 September 2014
doi:10.1186/1471-2105-15-S10-P32

Cite this article as: Phillips et al: Algorithmic tools for tripartite data analysis. BMC Bioinformatics 2014 15(Suppl 10):P32.
Submit your next manuscript to BioMed Central and take full advantage of:

- Convenient online submission

- Thorough peer review

- No space constraints or color figure charges

- Immediate publication on acceptance

- Inclusion in PubMed, CAS, Scopus and Google Scholar

- Research which is freely available for redistribution

\section{() Biomed Central}

Tennessee, Knoxville, TN 37996, USA

Full list of author information is available at the end of the article

(0 2014 Phillips et al; licensee BioMed Central Ltd. This is an Open Access article distributed under the terms of the Creative Commons Attribution License (http://creativecommons.org/licenses/by/4.0), which permits unrestricted use, distribution, and reproduction in any medium, provided the original work is properly cited. The Creative Commons Public Domain Dedication waiver (http:// creativecommons.org/publicdomain/zero/1.0/) applies to the data made available in this article, unless otherwise stated. 